\title{
A DESCRIPTION HIGHLIGHTING THE PSYCHOSOCIAL PROBLEMS EXPERIENCED BY LEARNERS IN THREE SECONDARY SCHOOLS IN THE WESTERN CAPE
}

\section{Philip Geldenhuys, Annemarie Youngleson}

\section{INTRODUCTION}

This paper provides a description of the psychosocial problems experienced by learners in three secondary schools in the Western Cape. This research aimed at eliciting the personal experiences of learners and then describing these data in comparison with current theoretical knowledge. The results of this research have been used as the scientific underpinning for the development of a multidisciplinary support service to learners in Western Cape secondary schools: the primary aim of the Community Keepers (CK) organisation.

$\mathrm{CK}$ is a non-profit organisation that exists to serve the community by addressing various psychosocial problems and needs within South African schools. CK aims to establish long-term relationships with school communities (learners, educators and parents) and to collaborate with these groups to find solutions to the challenges facing contemporary societies. This aim is accomplished through a unique approach to service and support, where professionals from diverse disciplines collectively form a team that assists individuals and families in a holistic way. The multidisciplinary team delivering the service will ideally consist of a social worker, clinical psychologist, educational psychologist, dietician, occupational therapist and school counsellor.

It is important to describe the context within which the research took place. The three schools selected to form part of this research are classified as Quintile $5^{3}$ schools. Although these schools offer opportunities for underprivileged learners, the majority of the learners are from middle to upper-class socio-economic groups. The schools are well resourced and selfsustainable. Within these schools the learners who were selected varied in terms of race, age, gender and current school grade.

This paper therefore sets out to describe the comparisons of self-reported psychosocial experiences of learners in these three schools across one specific domain (problems). The purpose of subsequent research will be to implement a multidisciplinary intervention specifically tailored to the felt needs of the learners. Ultimately intervention will be aimed at addressing psychosocial issues in adolescents in secondary schools.

\section{MOTIVATION FOR THE RESEARCH}

This research project was initially sparked by a concern and curiosity which developed from observations made in the media as well as from direct experiences in clinical practice in the community (Marshall \& Rossman, 1999; Mouton, 2001). For example, the South African Institute of Race Relations (2008) reports that South African schools are the most dangerous in the world.

\footnotetext{
${ }^{3}$ Quintile 5 schools can be defined as schools that are subsidised by the government at a rate of R129 per child per year and the rest of the costs are covered through school fees and private funds. This is in contrast to a Quintile 1 school, which receives $\mathrm{R} 775$ per child per year (www.wced.wcape.gov.za/circulars/circulars07/e51_07.html).
} 
Although the majority of the media hype around schools focuses on the extreme cases of violence and crime, other less prominent problems are evident within the school system. Visser (2003) explains that international tendencies indicate that when a nation has undergone drastic socio-economic and political change, as has happened in South Africa, changes often echo within a sphere of risk behaviour. Thus social problems in schools cannot be explained in terms of a linear progression, but only as a manifestation of problems in the wider society. It can therefore be concluded that the social ills of the community not only negatively influence the school system as a whole, but also the role-players individually. Liebenberg-Siebert and Smit (2001) state that higher success rates of schools are dependent on substantial psychosocial changes in society. It would seem that external forces from the community have a far-reaching and prevailing influence on the functioning of learners.

\section{PROBLEM STATEMENT}

Essentially, it seems that the successful functioning of secondary school learners is closely linked to the psychosocial functioning of the community and society (Schorr, 1997:283). Furthermore, there seems to be a problem with high-risk behaviour among adolescents in secondary schools in South Africa. The Youth Risk Behaviour Survey (Department of Health, 2002) is a document that clearly outlines the prevalence of key risk behaviours among South African youths. This survey consisted of sampling 23 schools per province, within which 14766 learners from Grades 8-11 were sampled and 10699 participated. The following are a few findings as indicated by learners who participated in this survey:

- In the previous six months, $19 \%$ had considered suicide and 17\% had attempted suicide;

- $41 \%$ had been bullied in the previous month;

- Alcohol consumption ranged from $49 \%$ having used it before, $32 \%$ for drinking in the previous month, and $23 \%$ had engaged in binge drinking in the previous month;

- Drug consumption varied from 13\% having used dagga, $12 \%$ heroin, $11 \%$ inhalants and $6 \%$ Mandrax;

- With regard to sexual behaviour, $41 \%$ of learners had had sex. Among the learners who had had sex before, $54 \%$ had had more than one past sexual partner, $70 \%$ had had sex in the past three months, only $29 \%$ practised consistent condom use and $16 \%$ had been pregnant.

This highlighted the need for a detailed description of the psychosocial problems experienced by learners in the secondary school environment. The critical lack of detailed information on this topic hinders the process of intervention with this population and the development of specific interventions aimed at targeting problems and needs highlighted by the population.

\section{GOAL OF THE RESEARCH}

Following from the above, the overall goal of this paper is to give a description of the personal and communal psychosocial problems experienced by learners in three secondary schools in the Western Cape.

\section{RESEARCH METHODOLOGY}

A qualitative paradigm was chosen for this research because the purpose of the study was to give a description of the perceptions and experiences of learners (Babbie, 2001:36-37; De Vos, Strydom, Fouché \& Delport, 2005:74; Murray \& Chamberlain, 2000; Neuman 2000:417-418). A phenomenological research design was implemented for this study (Patton, 2002:69). According to De Vos et al. (2005:273), the phenomenological approach aims to understand and 
interpret the meaning that subjects give to their everyday lives. This enabled the researchers to simultaneously develop an understanding of the phenomena described, during the process of describing them (Alston \& Bowles, 2003:34-35; De Vos et al., 2005:106).

\section{Interviewing process}

In-depth personal interviewing and naturalistic observation (Mitchell \& Jolley, 2001:441; Rubin \& Babbie, 2001:388-389), using a semi-structured interview schedule, were used in this study to gain a detailed picture of the participants' beliefs and perceptions (De Vos et al., 2002:302; Neuman, 2000:271-274; Padgett, 1998:373-374). The researchers themselves were involved and responsible for the fieldwork, which consisted of semi-structured questionnaires presented in an interview style as open-ended questions. This enabled the researchers to focus on specific problems experienced by learners, while allowing flexibility to elaborate on personal psychosocial issues (De Vos et al., 2005:292). All the interviews were tape-recorded and transcribed in order to ensure accuracy and efficiency in obtaining the information. The themes and sub-themes that emerged from the data were then used to generate categories to order the information (Cresswell, 1998; Marshall \& Rossman, 1999). These themes included the psychosocial, educational, recreational and physical aspects. For the purposes of this article, the researchers have chosen to focus on the psychosocial themes.

\section{Sampling}

Patton (2002) explains that there are no specific stipulations for sample size in qualitative research and that this is mainly determined through the logic of replication: samples are therefore based on saturation. One of the main factors influencing the learner sample was access to informed consent. This process of obtaining consent was in itself a method of selecting the sample size as many of the learners were not able to participate in the study because they did not bring back their consent forms. Attempts were made to obtain informed consent by handing out a detailed letter highlighting the goal of the investigation and its possible advantages and disadvantages; it also indicated the credibility of the researchers (De Vos et al., 2005:106). All consent was obtained on a voluntary basis and no participants were included in the study unless express written consent was given by their parents/guardians. A random sample was then selected from all the returned forms for respondents to participate in the individual interview process. In total 60 individual learners were interviewed.

TABLE 1

POPULATION AND SAMPLE SIZES OF LEARNERS

\begin{tabular}{|l|l|}
\hline Learner population & 2385 \\
\hline Learner sample & 60 \\
\hline
\end{tabular}

\section{Ethical considerations}

Throughout this study careful consideration was given to adhering to the ethical guidelines around completing research with minors. Padgett (1998:36) notes the importance of getting permission from the authoritative structures when proceeding with research. For this reason, permission from the Western Cape Educational Department was obtained in April 2008 before commencing with the study. After obtaining this permission, every principal of every school where research would be done was approached with a formal research proposal; all principals gave their consent for participation in the study. The researchers paid careful attention to the following issues: informed consent, anonymity, confidentiality, privacy, and preventing harm 
and/or deception of respondents (De Vos et al., 2005:63-69; Monette, Sullivan \& Jong, 1998:55-63).

\section{Limitations}

A number of limitations were taken into consideration in this study. Of primary concern was the fact that the learner sample was limited by the number of learners who brought back their consent forms. As a result, the sample obtained was randomly selected from this population and not the greater population. This places limitations on representation; however, this was deemed as of lesser importance in the context of qualitative research.

CK recognised the need for an investigation that focuses on the personal experiences of learners in a Quintile 5 school setting. There is limited literature and data sets that focus on the problems experienced by this specific group in the population and there is a gap in understanding and knowledge regarding the experience of the individual learner within the scope of the larger educational system (Visser \& Moleko, 1999). However, the scope for generalisation beyond these results is limited - as these results are based on findings within a Quintile 5 school setting and therefore may not be comparable to results that would be obtained from a different school context.

An additional limitation is the fact that the interviews took place on the school grounds. This could have had a detrimental impact on the quality of the responses obtained, seeing that respondents may have felt inhibited or not been able to give their full attention to the researchers.

\section{THEORETICAL FRAMEWORK}

Psychosocial problems can be defined within the area of human functioning, where there is a desire, but not the means, to change a situation - specifically pertaining to one's psychological (emotional and cognitive) development within and in interaction with a social environment (school, family and friends) (Reber, 1995:620). Adolescence has been identified as a period of dramatic change second only to the first two to three years of children's lives (Eccles, 1999). Thus adolescents, at this critical stage of their overall development, are particularly vulnerable to developing psychosocial problems when there is a negative impact on their development.

Bronfenbrenner (1979) proposed a theoretical framework for understanding human functioning. He believed that proximal processes (the exchanges of energy between the developing person and the environment) are the building blocks for human development. This theoretical framework states that proximal processes need to take place on a regular basis over extended periods of time in order for effective development to occur. During childhood and early adolescence, proximal processes occur within three key ecological contexts: with family, friends and wider societal structures and norms (Bronfenbrenner, 1979; Bronfenbrenner \& Evans, 2000). For the purposes of this study, the researchers have chosen to focus on the psychosocial problems, as described by the learners, within the family and peer contexts, which give rise to problems in the effective development of the adolescents involved.

\section{FAMILY}

The family system is arguably the entity with the greatest influence on the development and functioning of any individual. Families go through various positive and negative transitions, which could include the birth of children, initiation of schooling or the loss of a parent as a result of divorce or death (Zastrow, 2004:55). These transitions can be interpreted as times of disequilibrium in the family system, when family stability is threatened by the demand for 
change, and they usually have a negative impact on the proximal processing of the individual (Goldenberg \& Goldenberg, 1998:37). Unsuccessful transitions may result in tensions between family members which can manifest in behavioural problems. When left uncorrected, these behavioural problems can develop into established negative behavioural patterns (Germain \& Gitterman, 1986:630). Consequently the psychosocial wellbeing of an adolescent will directly and indirectly be influenced by times of family disequilibrium that could emanate from a range of causes: from physical (divorce) to emotional (neglect). Prior, Ruschena, Sanson and Smart (2005) highlight divorce, parental separation, remarriage and death as family transitions that could contribute to psychosocial problems in adolescents.

\section{Divorce}

Parental divorce is considered one of the most significant and stressful events that children and adolescents may have to face. The severity of this event is mediated by the quality of the parent-child relationship (Farrington, 2002; Gottfredson \& Hirschi, 1990; Greeff \& Watson, 2004; Holmen, Roysamb, Stroksen \& Tambs, 2006). In situations where the parents are unable to facilitate effective processing of divorce, adolescents are faced with psychosocial problems which impede effective emotional and social development.

\section{Death}

Similarly, parental death results in negative consequences for each family member individually and the family as a whole. Research shows that the surviving parent's ability to cope with the loss of their partner will largely impact on the adolescent's grieving process (Hamrin \& Kirwin, 2005). The death of a parent can negatively affect a child's self-concept, health and social functioning, if the task of grieving is not facilitated in a supportive environment (Hamrin \& Kirwin, 2005).

\section{Single parents}

Research has found that single-parent families increase the risk of adolescents becoming involved in negative social behaviour and delinquency (Farrington, 2002:426; Frank, 2005:12; Guerra, 2002:xvi; Hamrin \& Kirwin, 2005:70; Popenoe, 1996:142). Furthermore, parental involvement fosters the development of children's character that is conducive to successful psychosocial functioning (Baumeister, Engels \& Finkenauer, 2006:58). In a study focusing on youth offenders, Geldenhuys (2007) notes that adolescents have a dire need for emotional support and guidance from parents or guardians, and the absence of this could lead to psychosocial problems and negative behavioural patterns. The involvement of parents in the lives of their children can be described as a protective factor: possibly increasing the adolescent's capacity to help themselves and to prevent the development of psychosocial problems.

\section{FRIENDS}

Although family relationships remain important throughout life, peer relationships become an increasingly significant influence on adolescents' lives (Vaux, 1988). Adolescents are consciously and unconsciously looking for role models (generally amongst peers) whom they can follow. Nation and Heflinger (2006) confirm that peer relationships are powerfully influential on the attitudes and behaviour of adolescents. Adolescence is synonymous with various physical, emotional and behavioural changes. During this period teenagers are more likely to engage in risk-taking behaviour, which can have psychological and social outcomes. 
At times this risk-taking behaviour may impede the accomplishment of normal developmental tasks and the fulfilment of expected social roles (Jessor, 1991).

\section{Sexual behaviour}

Risk-taking behaviour commonly manifests in the area of adolescent sexual interactions. Various studies indicate that dating and sexual activities which occur earlier than same-age peers, and sexual intercourse that occurs without adequate protection, are sources of psychosocial and health risks for youth (Costa, Jessor, Donovan \& Fortenberry, 1995; Costa, Jessor, Fortenberry \& Donovan, 1996; Stattin \& Magnusson, 1990). Adolescents commonly exhibit careless sexual behaviour or promiscuity, which has been proved to have detrimental consequences on their psychosocial functioning (Goodenow, Netherland \& Szalacha, 2002:203).

\section{Substance use/abuse}

Although numerous factors can account for adolescent substance use, the predominant reason seems to involve the fact that adolescence is a period of transition, wherein impulsivity, recklessness and non-conforming behaviour manifest more prominently than in any other developmental stage (Madge \& Harvey, 1999). Reviews of research exploring the nature of substance use during adolescence repeatedly highlight the critical role peer relationships play concerning the onset and escalation of alcohol and drug use (Petraitis, Flay \& Miller, 1995). The literature (Dishion, Capaldi, Spraklen \& Li, 1995) highlights that peer influences are also critically important in the onset of substance use in adolescents, and that drug and alcohol use among close peers appears to influence the initiation and maintenance of drug use by adolescents (Nation \& Heflinger, 2006).

The current profile of alcohol abuse among South African adolescents in many ways mirrors the trends found globally among adolescents (Parry, Myers, Marojele, Flisher, Bhana, Donson \& Pluddemann, 2004). Mostly the initiation of alcohol use and experimentation during adolescence is considered normative; however, there are incidences where excessive binge drinking is described (Clark, Bukstein \& Cornelius, 2002). In a study which took place among Cape Town Grade 11 learners it was reported that the proportion of learners who had used tobacco, alcohol and cannabis in the previous month was $27 \%, 31 \%$ and $7 \%$ respectively (Flisher, Muller \& Lombard, 2004).

In general, there is a scarcity of information on the extent of drug use amongst South African young people (Visser \& Routledge, 2007). Based on the studies available, it would seem that a relatively small minority of teenagers use illicit drugs in community populations (Clark et al., 2002) and that the majority of adolescents using drugs in South Africa use cannabis (Flisher, Parry, Evans, Lombard \& Muller, 2003). Interestingly, the literature review for this study revealed that very little is known about alcohol and drug use among adolescents living in affluent social settings as most of the research focuses on lower socio-economic settings. It is generally presumed that social and economic advantages decrease the risk of psychosocial problems; however, research (McMahon \& Luthar, 2006) indicates that substance use may occur as frequently, if not more so, among children living in affluent suburban communities.

\section{IDENTIFYING PARTICULARS}

In order to fully understand the results, it is necessary to provide an accurate description of the sample population from which the findings were obtained. Tables 1-4 reflect the sample sizes that were used in this study and have been grouped in terms of the selection criteria used in the sampling process. 
TABLE 2

REFLECTION OF THE LEARNER SAMPLE SIZE ACCORDING TO AGE

\begin{tabular}{|l|c|c|}
\hline Age & Number of learners & \% of total \\
\hline $13-14$ years & 13 & $21.67 \%$ \\
\hline $15-16$ years & 26 & $43.33 \%$ \\
\hline $17-18$ years & 21 & $35 \%$ \\
\hline Total & $\mathbf{6 0}$ & $\mathbf{1 0 0 \%}$ \\
\hline
\end{tabular}

The 15-16 years age bracket represents learners from Grades 8, 9, 10 and 11. As a result the highest percentage of learners naturally fell within this age bracket.

TABLE 3

REFLECTION OF THE LEARNER SAMPLE SIZE ACCORDING TO GENDER

\begin{tabular}{|l|c|c|}
\hline Gender & Number of learners & \% of total \\
\hline Male & 25 & $41.67 \%$ \\
\hline Female & 35 & $58.33 \%$ \\
\hline Total & $\mathbf{6 0}$ & $\mathbf{1 0 0 \%}$ \\
\hline
\end{tabular}

The difference between female and male respondents can be attributed to the process of random sampling, whereby more females were interviewed than males.

\section{RESEARCH RESULTS}

Table 4 presents a description of the psychosocial problems of those who participated in this study:

TABLE 4

\section{PROBLEMS EXPERIENCED BY LEARNERS}

\begin{tabular}{|c|c|c|}
\hline $\begin{array}{c}\text { SUB } \\
\text { THEME }\end{array}$ & $\begin{array}{l}\text { CATE- } \\
\text { GORIES }\end{array}$ & NARRATIVE FROM INTERVIEWS \\
\hline \multirow[t]{3}{*}{$\begin{array}{l}\text { 1. Family } \\
\text { Problems }\end{array}$} & 1.1 Divorce & $\begin{array}{l}\text { “My parents have been divorced since I was } 6 \ldots \text { you don't really get over } \\
\text { it." } \\
\text { "My ouers is geskei toe ek in graad } 4 \text { was... my pa... ek dink hy is nou al } \\
\text { so } 4 \text { keer getroud en geskei... ek weet hy het my ma 'n paar keer verneuk } \\
\text { toe hulle nog saam was.” [My parents were divorced when I was in Grade } \\
4 \ldots \text { my father... I think he has remarried and divorced about } 4 \text { times since } \\
\text { then... I know that he was unfaithful a few times when he was still with my } \\
\text { mother.] } \\
\text { "Family life is not good...my parents are divorced... before Grade } 8 \text { she } \\
\text { (mother) tried to commit suicide... I shut myself down." }\end{array}$ \\
\hline & $\begin{array}{ll}1.2 & \begin{array}{l}\text { Death of } \\
\text { parent }\end{array}\end{array}$ & $\begin{array}{l}\text { "Pa is oorlede... oor die jare het hy (stiefpa) goed aan my ma gedoen } \\
\text { waarvan ek nie gehou het nie... glad nie met hom gepraat van die dag dat } \\
\text { hulle getrou het." [Father died... over the years he (stepfather) has done } \\
\text { things to my mother which I do not like... I have not spoken to him since } \\
\text { the day that they married.] } \\
\text { "My ma is oorlede toe ek } 4 \text { maande oud is en my pa het ons toe gelos so ek } \\
\text { bly eintlik by my ouma en oupa... ek ken hom (pa) glad nie." [My mother } \\
\text { died when I was } 4 \text { months old and my father left us then, so I actually live } \\
\text { with my grandmother and grandfather... I don't know him (father) at all.] }\end{array}$ \\
\hline & $\begin{aligned} 1.3 & \text { Single- } \\
& \text { parents }\end{aligned}$ & $\begin{array}{l}\text { "Sometimes I don't feel like coming to school because my mom is a single } \\
\text { parent. If things are going bad at home, it kind of affects my school life." } \\
\text { "As ek by die huis is dan raak alles te swaar vir my. My ma en haar }\end{array}$ \\
\hline
\end{tabular}




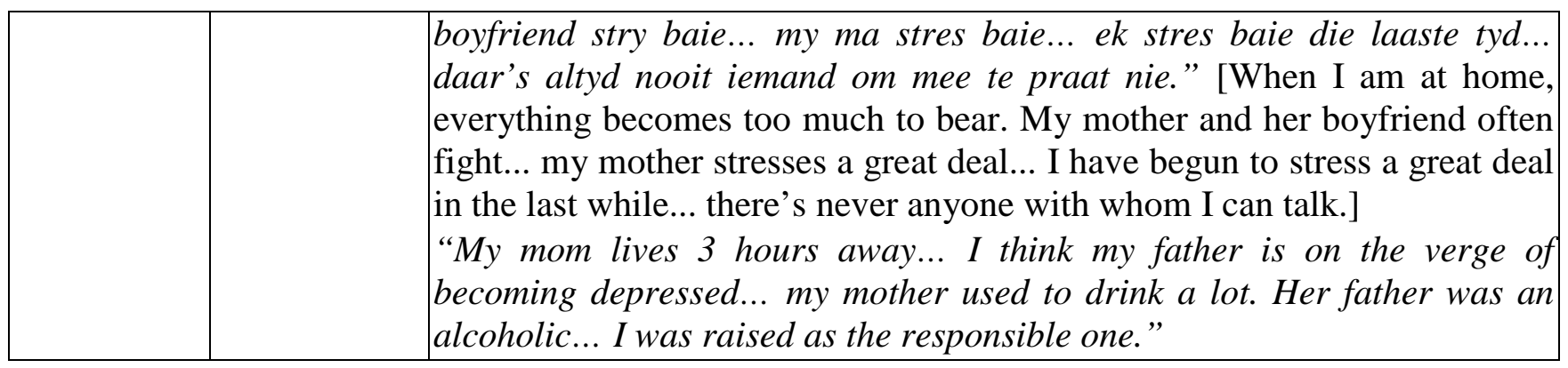

The results indicate that divorce is experienced as a distressing psychosocial stressor. Respondents implied that there was little support available during and after the divorce for them and their families. This correlates with the findings of Greeff and Watson (2004) and Farrington (2002), which note the destructive consequences divorce has on children when the necessary support is not received from the parental relationship. Resentment towards one or both of the parents (for their role in the separation, before and after the divorce) as identified by the participants, provided additional confirmation of the negative impact of this life event on the psychosocial functioning of these adolescents.

Parental death was experienced as a psychosocial problem because of the drastic influence it had on participants' individual and family lives. It seemed as if the influence of this event was diminished by the positive ability of the other parent to successfully cope and adapt afterwards. This confirms the findings of Hamrin and Kirwin (2005) on the negative effects that the death of a parent can have on a child if the task of grieving is not facilitated in a supportive environment. Participants also referred to the compounding effect of relocation and remarriage of their surviving parent and their negative experience of these events in addition to the initial parental death. The inability to change the circumstances around parental death makes this event a serious psychosocial problem for participants.

Participants emphasised the lack of support in single-parent families and reported manifold psychosocial problems in these settings. This correlates with the findings of Baumeister et al. (2006) and Maree (2003) on the need that adolescents have for emotionally involved and interested parents. Participants complained that the lack of parental involvement impeded their own ability to cope with everyday challenges: this parallels findings by Frank (2005) and Hamrin and Kirwin (2005). The participants felt that better emotional support from a parent could enhance their own psychosocial functioning. 
TABLE 4 (CONTINUED) PROBLEMS EXPERIENCED BY LEARNERS

\begin{tabular}{|c|c|c|}
\hline SUBTHEME & CATEGORIES & NARRATIVE FROM INTERVIEWS \\
\hline \multirow[t]{2}{*}{$\begin{array}{l}\text { 2. Substance } \\
\text { use }\end{array}$} & 2.1 Alcohol & $\begin{array}{l}\text { "Daar's 'n fase wat 'n mens deurgaan wat jy alkohol } \\
\text { misbruik maar nou is dit niks. Drink het soos 'n instelling } \\
\text { geraak, soos } 2 \text { dae 'n week gaan ons uit... en dan raak die } \\
\text { ouens trashed." [There's a phase which people go through } \\
\text { where they misuse alcohol, but now it's nothing. Drinking has } \\
\text { become like an institution, like } 2 \text { days a week, we go out... } \\
\text { and then the guys get trashed.] } \\
\text { "Drinking has become sort of culture... girls are really } \\
\text { struggling with alcohol over weekends... unwind after a long } \\
\text { hard week." } \\
\text { "Daar is kinders wat soos elke naweek kuier ... daar is 'n } \\
\text { hele paar wat kuier om elke naweek dronk te word." [There } \\
\text { are children who like drink every weekend... there is a whole } \\
\text { bunch who drink in order to get drunk every weekend.] }\end{array}$ \\
\hline & 2.2 Drugs & $\begin{array}{l}\text { "Ons rook dagga in die natuur... in die park... kry by 'n rasta } \\
\text { in die omgewing... hy het ' } n \text { spesifieke plek waar hy dit } \\
\text { verkoop." [We smoke dagga in nature... in the park... get it } \\
\text { from a rasta in the vicinity... he has a specific place where he } \\
\text { sells it.] } \\
\text { "House parties... there are a few (learners) that smoke... use } \\
\text { drugs... dagga, not any hard core drugs." }\end{array}$ \\
\hline
\end{tabular}

The results of this study indicate that alcohol was the most common substance used among the adolescents interviewed. This correlates with the findings of Flisher et al. (2004). Learners reported that the excessive use of alcohol was regarded as the norm and a means of connecting socially with other learners. There seemed to be polar responses to binge drinking - those who considered it an "institution" and those who were ashamed of the behaviour of their peers. Research conducted in South Africa by Visser and Routledge (2007) confirms that many adolescents engage in substance use activities, which they perceive as risky, but yet somehow acceptable within their peer groups. Learners did not seem to be concerned about the health risks of excessive alcohol use, although the literature highlights that substance abuse among adolescents in South Africa is one of the most significant health and social problems (Flisher et al., 2003).

Generally the use of drugs amongst learners was not reported as problematic. It would seem that those who are involved with drug use mainly smoke cannabis (as opposed to using "hard" drugs). Findings by Flisher et al. (2003) confirm this. The learners described using drugs in social gatherings rather than when alone; however, these learners seemed to be in the minority. The literature on adolescent drug use in South Africa is limited, especially with respect to affluent settings (Visser \& Routledge, 2007). This may be indicative of the more prominent effects of alcohol rather than drug use in this population. However, it is possible that the lack of information on drug use is a result of learners' reluctance to discuss drug use, which may be considered a social taboo in some communities. 
TABLE 4 (CONTINUED)

PROBLEMS EXPERIENCED BY LEARNERS

\begin{tabular}{|c|c|c|}
\hline SUBTHEME & CATEGORIES & NARRATIVE FROM INTERVIEWS \\
\hline \multirow[t]{4}{*}{$\begin{array}{l}\text { 3. Sexual } \\
\text { behaviour }\end{array}$} & \begin{tabular}{|ll}
3.1 & Peer \\
& pressure
\end{tabular} & $\begin{array}{l}\text { "If you haven't done it (sex), how are you going to feel? You're going } \\
\text { to feel like an outcast." } \\
\text { "In die hoërskool dink die kinders baie anders oor verhoudings... } \\
\text { begin sien hoe jou vriende dink daaroor en dan betwyfel jy of jou } \\
\text { wyse van dink reg is... moeilik om te onderskei wat nou reg en } \\
\text { verkeerd is... want hy (ou) sal sê, 'as jy lief is vir my, dan sal jy dit } \\
\text { (seks) doen'... en dan los hy jou agterna." [In high school, children } \\
\text { think very differently about relationships... begin to see how your } \\
\text { friends think and then you doubt whether your way of thinking is } \\
\text { correct... difficult to distinguish between right and wrong... because } \\
\text { he (a guy) will say, 'if you love me, then you'll have sex with me'... } \\
\text { then he leaves you afterwards.] }\end{array}$ \\
\hline & \begin{tabular}{|ll}
3.2 & Sexual \\
& activity in \\
& adolescence \\
& is "normal"
\end{tabular} & $\begin{array}{l}\text { "Die meeste het al seks gehad... hulle (kinders) praat sommer } \\
\text { daaroor op die strate, miskien, 'sy het saam met hom geslaap', dis nie } \\
\text { meer 'n issue nie." [Most have already had sex... they (children) even } \\
\text { talk about it openly on the street, say for instance 'she's slept with } \\
\text { him,' it's no longer an issue.] } \\
\text { "As jy uitgaan oor naweke, by partytjies by huise, dit (seks) gebeur, } \\
\text { dis nie net op die TV nie... baie ouens is seksueel aktief... hulle is } \\
\text { meestal in verhoudings.” [If you go out over weekends, to parties at } \\
\text { peoples' houses, it (sex) happens, it's not only on TV... many guys } \\
\text { are sexually active... they are mainly in relationships.] }\end{array}$ \\
\hline & 3.3 Regret & $\begin{array}{l}\text { "Die grootste fout was om my virginity weg te gooi. My ma en pa kon } \\
\text { dit gekeer het as hulle eie probleme uitsorteer sou wees... het die } \\
\text { eerste keer met 'n ou geslaap in Graad 9... dit was 'n slegte } \\
\text { ervaring." [The biggest mistake was to throw away my virginity. My } \\
\text { mother and father could have prevented it, if their own problems were } \\
\text { sorted out... I slept with a guy for the first time in Grade 9... it was a } \\
\text { horrible experience.] } \\
\text { "One of my close friends had a boyfriend and they slept together and } \\
\text { now have broken up. She's actually really having a hard time and is } \\
\text { actually failing Grade 10... she's really struggling with normal life } \\
\text { stuff because all she can think about is him." }\end{array}$ \\
\hline & 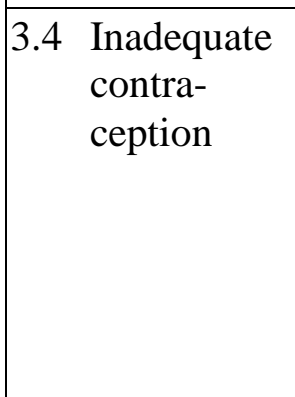 & $\begin{array}{l}\text { "In ons graad van in die } 130 \text { kinders was daar oor die } 60 \text { kinders wat } \\
\text { al seksueel aktief is... weet vir 'n feit hulle het al seks gehad... 'n } \\
\text { paar meisies wat aborsies gehad het... baie meisies wat kliniek toe } \\
\text { gaan vir die 'morning after' pil." [In our grade of about } 130 \text { children, } \\
\text { there are over } 60 \text { children who are already sexually active... I know } \\
\text { for a fact that they have had sex already... know of a few girls who } \\
\text { have had abortions... many girls who go to the clinic for the } \\
\text { "morning-after' pill.] }\end{array}$ \\
\hline
\end{tabular}

The results indicate that peer pressure predominantly influenced adolescents' perceptions of sexual behaviour. Many of the respondents felt that their contemporaries were engaging in sexual behaviour because of the pressure to conform and to feel accepted within their peer 
group. This confirms findings by Vaux (1988), who emphasised the significant influence of peer relationships in adolescence.

Although sexual activity amongst adolescents was largely considered the norm, the results indicated that several of the learners felt uncomfortable with the notion that their contemporaries (of the same age) were engaging in sexual behaviour. Research conducted in South Africa indicates that the average age of first sexual encounter in South Africa is 17 years for young women and 16.4 years for young men (Reproductive Health Research Unit, 2004). However, the results from this study indicated that many of the respondents were well below this age group. Costa et al. (1995) highlight that early sexual debut increases psychosocial vulnerability. Learners seemed to be aware of this increased risk, even if only on an intuitive level.

Despite the notion amongst the respondents that sexual activity during adolescence is 'normal', some of the learners (predominantly female) reported a sense of regret (either for themselves or their friends) concerning sexual debut. They explained that the results of previous sexual actions still have negative repercussions in their lives at present. Weichold, Silbereisen and Schmitt-Rodermund (2003) state that early sexual involvement is related to overall poor adjustment in adolescence.

Learners reported concerns about the poor use of contraception amongst friends and noted an increasing number of pregnancies. This was most often remedied through abortion or the 'morning-after' pill as opposed to increased measures of contraception. Research by Lesch and Bremridge (2006) highlights the prevalence of unprotected sex amongst teenagers in this region, and confirms that the adolescent population is at risk.

\section{DISCUSSION}

The aim of the research is to provide a description of the psychosocial problems experienced by the adolescent learners interviewed in three Quintile 5 schools in the Western Cape area. The psychosocial problems described by the learners in this study strongly parallel the findings of the Department of Health's Youth Risk Behaviour Survey of 2002. The results highlight two areas of concern: problems within the family setting and problems amongst peer groups (usually because of a sense of peer pressure). These problems were deemed age appropriate and seemed to occur predominantly in interactions in these two settings. It is important to bear in mind that, according to Bronfenbrenner (1979), there is a reciprocal relationship between the individual and his/her surrounding systems. As a result, psychosocial problems which manifest in an individual's life often mirror and interact with problems in the wider systems of society. The results of this study therefore emphasise the significant role that family and peer relationships play in the development and functioning of the adolescent.

Through the research process, a second area of interest began to develop, although it was initially not part of the focus of the study. While interacting with members from the schools and surrounding community, the researchers began to realise that there is a common misperception that learners from above-average socio-economic settings do not have psychosocial problems, and that the resources in these settings adequately provide for the needs of the learners. However, on closer examination the results revealed that many of these learners have significant psychosocial problems that are currently not sufficiently addressed in their school and home environments. In addition, the literature review revealed a paucity of information on the psychosocial needs and problems of learners from affluent settings; most articles focused on the problems of learners in low socio-economic settings. It would seem that 
the voice of the "privileged" learner is not being heard, despite evidence that he/she may have significant psychosocial problems.

\section{CONCLUSION AND RECOMMENDATIONS}

The results of this study indicate that family and peer-related psychosocial problems were the most significant factors interfering with the effective functioning of these adolescents. The authors recommend that additional research should be completed focusing on the accessibility of resources for adolescents. The focus of such supplementary research could be aimed at ascertaining the perceptions of adolescent learners concerning the availability of resources within the family, peer and school systems.

This study aimed at identifying and providing a description of the psychosocial problems experienced by adolescent learners in these three Quintile 5 schools; however, there is still a need for additional research aimed at establishing causality of these psychosocial problems. This information will significantly support the design and implementation of future intervention strategies in these schools aimed at reducing the effects of psychosocial problems and preventing future problems.

\section{BIBLIOGRAPHY}

ALSTON, M. \& BOWLES, W. 2003. Research for social workers: an introduction to methods $\left(2^{\text {nd }}\right.$ ed). London: Routledge.

BABBIE, E. 2001. The practice of social research. Belmont: Wadsworth Publishing Company.

BAUMEISTER, R.F., ENGELS, R. C. M. E. \& FINKENAUER, C. 2006. Parenting behaviour and adolescent behavioural and emotional problems: The role of self-control. International Journal of Behavioral Development, 29(1):58-69.

BRONFENBRENNER, U. 1979. The ecology of human development. Cambridge: Harvard University Press.

BRONFENBRENNER, U. \& EVENS, G.W. 2000. Developmental science in the $21^{\text {st }}$ century: emerging theoretical models, research designs, and empirical findings. Social Development, 9:115-125.

CLARK, D.B., BUKSTEIN, O. \& CORNELIUS, J. 2002. Alcohol use disorders in adolescents epidemiology, diagnosis, psychosocial interventions, and pharmacological treatment. Pediatric Drugs, 4(8):493-502.

COSTA, F., JESSOR, R., DONOVAN, J.E. \& FORTENBERRY, J.D. 1995. Early initiation of sexual intercourse: the influence of psychosocial unconventionality. Journal of Research on Adolescence, 5:93-121.

COSTA, F., JESSOR. R., FORTENBERRY, J.D \& DONOVAN, J.E. 1996. Psychosocial conventionality, health orientation, and contraceptive use in adolescence. Journal of Adolescent Health, 18:404-416.

CRESWELL, J.W. 1998. Qualitative inquiry and research design: choosing among five traditions. Thousand Oaks: Sage Publications.

DEPARTMENT OF SOCIAL DEVELOPMENT. 2006. Final draft. National Policy on Families. [On line] Available: http://www.welfare.gov.za [Accessed: 17/11/2006]. 
DEPARTMENT OF HEALTH. 2002. The $\mathbf{1}^{\text {st }}$ South African National Youth Risk Behaviour Survey. [On line] Available: http://www.info.gov.za/otherdocs/2003/ youth/index. html. [Accessed: 13/02/2009].

DE VOS, A.S., STRYDOM, H., FOUCHÉ, C.B. \& DELPORT, C.S.L. (eds) 2005. Research at grass roots: for the social sciences and human services professions $\left(3^{\text {rd }} \mathrm{ed}\right)$. Pretoria: $\mathrm{Van}$ Schaik Publishers.

DISHION, T.J., CAPALDI, D.M., SPRAKLEN, K.M. \& LI, F. 1995. Peer ecology of male adolescent drug use. Development and Psychopathology, 7:803-824.

ECCLES, J.S. 1999. The development of children ages 6 to 14. The Future of Children, 9(2):30-44.

FARRINGTON, D. 2002. Understanding and preventing youth crime. In: HUGHES, G., McLAUGHLIN, E. \& MUNCIE, J. (eds) Youth justice: critical readings. London: Sage Publications.

FLISHER, A.J., MULLER, M. \& LOMBARD, C. 2004. Test retest reliability of self-reported adolescent risk behaviour. Journal of Adolescence, 27:207-212.

FLISHER, A.J., PARRY, C.D.H., EVANS, J., LOMBARD, C. \& MULLER, A. 2003. Substance use by adolescents in Cape Town: prevalence and correlates. Journal of Adolescent Health, 32:58-65.

FRANK, C. 2005. Young guns: children in organised crime. S.A. Crime Quarterly, 14:12-14.

GELDENHUYS, P.R. 2007. A multidimensional perspective on the family experiences and perceptions of male youth offenders. Stellenbosch: Stellenbosch University. (MA thesis)

GERMAIN, C.B. \& GITTERMAN, A. 1986. The life model approach to social work practice revisited. In: TURNER, F.J. (ed) Social work treatment: interlocking theoretical approaches. New York: The Free Press.

GOODENOW, C., NETHERLAND, J. \& SZALACHA, L. 2002. AIDS-related risk among adolescent males who have sex with males, females, or both: evidence from a statewide survey. American Journal of Public Health, 92:203-210.

GOLDENBERG, I. \& GOLDENBERG, H. 1998. Counseling today`s families $\left(3^{\text {rd }}\right.$ ed). Pacific Grove: Brooks/Cole Publishing Company.

GOTTFREDSON, M.R. \& HIRSCHI, T. 1990. A general theory of crime. Stanford: Stanford University Press.

GREEFF, A.P. \& WATSON, N.M. 2004. An analysis of schema theory and learning theory as explanations for variance in adolescent adjustment to divorce. The American Journal of Family Therapy, 32:437-448.

GUERRA, A.J. 2002. Family matters. St. Paul: Paragon House.

HAMRIN, V. \& KIRWIN, K.M. 2005. Decreasing the risk of complicated bereavement and future psychiatric disorders in children. Journal of Child and Adolescent Psychiatric Nursing, 18(1):62-78.

HOLMEN, T.L., ROYSAMB, E., STORKSEN, I. \& TAMBS, K. 2006. Adolescent adjustment and well-being: effects of parental divorce and distress. Scandinavian Journal of Psychology, 47:75-84. 
JESSOR, R. 1991. Risk behavior in adolescence: a psychosocial framework for understanding and action. Journal of Adolescent Health, 12:597-605.

LESCH, E. \& BREMRIDGE, C. 2006. Safe sex and constructions of young male sexuality in one semi-rural Western Cape community. South African Review of Sociology, 37(2):128-142.

LIEBENBERG-SIEBERT, L. \& SMIT, G. 2001. The training of teachers in using a life space crisis intervention strategy (LSCI). Perspectives in Education, 19(3):121-132.

MARSHALL, C. \& ROSSMAN, G.B. 1999. Designing qualitative research $\left(3^{\text {rd }} \mathrm{ed}\right)$. London: Sage Publications.

MADGE, N. \& HARVEY, J.G. 1999. Suicide among the young: the size of the problem. Journal of Adolescence, 22:145-155.

MAREE, A. 2003. Criminogenic risk factors for youth offenders. In: BEZUIDENHOUT, C. \& JOUBERT, S. (eds) Child and youth misbehaviour in South Africa. Pretoria: Van Schaik Publishers.

McMAHON, T.J. \& LUTHAR, S.S. 2006. Patterns and correlates of substance use among affluent, suburban high school students. Journal of Clinical Child and Adolescent Psychology, 35(1):72-89.

MITCHELL, M. \& JOLLEY, J. 2001. Research design explained. London: Harcourt College Publishers.

MONETTE, D.R., SUlLIVAN, T.J. \& DE JONG, C.R. 1998. Applied social research: tool for the human services. London: Harcourt College Publishers.

MOUTON, J. 2001. How to succeed in your master's and doctoral studies: a South African guide and resource book. Pretoria: Van Schaik Publishers.

MURRAY, M. \& CHAMBERLAIN, K. 2000. Qualitative methods and women's health research. In: USHER, J.M. (ed) Women's health: contemporary international perspectives. London: BPS Books.

NATION, M. \& HEFLINGER, C. 2006. Risk factors for serious alcohol and drug use: the role of psychosocial variables in predicting the frequency of substance use among adolescents. The American Journal of Drug and Alcohol Abuse, 32:415-433.

NEUMAN, W.L. 2000. Social research methods: qualitative and quantitative approaches $\left(4^{\text {th }}\right.$ ed). Boston: Allyn \& Bacon.

PADGETT, D.K. 1998. Qualitative methods in social work research. Thousand Oaks: Sage Publications.

PARRY, C.D.H., MYERS, B., MOROJELE, N.K., FLISHER, A.J., BHANA, A., DONSON, H. \& PLUDDEMANN, A. 2004. Trends in adolescent alcohol and other drug use: findings from three sentinel sites in South Africa (1997-2001). Journal of Adolescence, 27:429-440.

PATTON, M.Q. 2002. Qualitative research and evaluative methods. London: Sage Publications.

PETRAITIS, J., FLAY, B.R. \& MILLER, T.Q. 1995. Reviewing theories of adolescent substance abuse: Organizing pieces of the puzzle. Psychological Bulletin, 117:67-86.

POPENOE, D. 1996. Life without father. New York: Free Press. 
PRIOR, M., RUSCHENA, E., SANSON, A. \& SMART, D. 2005. A longitudinal study of adolescent adjustment following family transitions. Journal of Child Psychology and Psychiatry, 46(4):353-363.

REBER, A.S. 1995. Penguin Dictionary of Psychology ( $2^{\text {nd }}$ ed). England: Penguin.

REPRODUCTIVE HEALTH RESEARCH UNIT. 2004. HIV and sexual behavior among young South Africans: a national survey of 15-24 year olds. [On line] Available: http://rhru.witshealth.co.za/PublicationsDownloads/HIV\%20Management\%20page/National Y outh_Survey_Fact_Sheet.pdf. [Accessed: 10/07/2009].

RUBIN, A. \& BABBIE, E. 2001. Research methods for social work. Belmont: Wadsworth Thompson Learning.

SCHORR, L. B. 1997. Common purpose: strengthening families and neighborhoods to rebuild America. New York: Anchor Books.

SOUTH AFRICAN INSTITUTE FOR RACE RELATIONS. 2008. South African schools most dangerous in the world. [On line] Available: http://www.sairr.org.za/pressoffice/archive/south-african-schools-most-dangerous-in-the-world-2013-only-23-of-pupilssafsafe.html. [Accessed: 25/03/2009].

STATTIN, H. \& MAGNUSSON, D. 1990. Paths through life: vol. 2. Pubertal maturation in female development. Hillsdale, NJ: Lawrence Erlbaum Associates, Inc.

VAUX, A. 1988. Social support: theory, research and intervention. New York: Praeger.

VISSER, M. 2003. Risk behaviour of primary school learners in a disadvantaged community a situational analysis. South African Journal of Education, 23(1):58-64.

VISSER, M. \& MOLEKO, A. 1999. High-risk behaviour of primary school learners. Urban Health and Development Bulletin, 2:69-77.

VISSER, M. \& ROUTLEDGE, L.-A. 2007. Substance abuse and psychological well-being of South African adolescents. South African Journal of Psychology, 37(3):595-615.

WEICHOLD, K., SILBEREISEN, R.K. \& SCHMITT-RODERMUND, E. 2003. Short-term and long-term consequences of early vs. late physical maturation in adolescents. In: HAYWARD, C. (ed) Gender differences at puberty. Cambridge England: Cambridge University Press.

ZASTROW, C. 2004. Introduction to social work and social welfare: empowering people $\left(8^{\text {th }}\right.$ ed). Belmont: Brooks/Cole Publishing Company.

Mr Philip Geldenhuys, social worker at Community Keepers, Stellenbosch, South Africa; Ms Annemarie Youngleson, clinical psychologist in private practice and employed part-time by Community Keepers, Stellenbosch, South Africa. 